\title{
Particle size selectivity and resource partitioning in five species of Thalassinidea (Crustacea: Decapoda)
}

\author{
Eunice H. Pinn, R. James, A. Atkinson*, Andrew Rogerson** \\ University Marine Biological Station, Millport, Isle of Cumbrae, KA28 0EG, United Kingdom
}

\begin{abstract}
Particle selectivity was examined in Calocaris macandreae, Callianassa subterranea, Jaxea nocturna, Upogebia deltaura and $U$. stellata by comparing the inorganic particle size range within the gut with that from their respective environments. C. subterranea and C. macandreae are both deposit feeders, whilst $J$, nocturna is a re-suspension feeder, i.e. this shrimp flicks up deposited material ahead of the mouthparts and suspension feeds. $U$. deltaura and $U$. stellata are both predominantly suspension feeders. Particle size selectivity was not observed for either $C$. macandreae or $J$. nocturna. When the particle size range of the sediment taken from the upogebiid site was compared with that of the gut, particle selectivity was observed for both species. When particle size distribution from the gut was compared to that of the water column, however, no such evidence of particle selectivity was noted. For C. subterranea, no evidence of particle selectivity was observed in the specimens taken from a very fine muddy sediment. However, those taken from a sandier site showed clear evidence of particle selectivity. Interspecific and intraspecific particle size selection is discussed in relation to resource partitioning.
\end{abstract}

KEY WORDS: Callianassa Calocaris - Upogebia $\cdot$ Resource utilization

\section{INTRODUCTION}

Over the last 20 yr a number of models have been produced linking burrow morphology and feeding behaviour in the Thalassinidea (Ott et al. 1976, Suchanek 1985, de Vaugelas 1990, Griffis \& Suchanek 1991). Although there is a large amount of literature on thalassinidean burrow architecture, relatively little is known about the feeding behaviour and diet of specific thalassinideans. This severely limits the usefulness of the burrow morphology/feeding mode models (Nickell \& Atkinson 1995).

Members of the Thalassinidea are generally considered to be deposit or suspension feeders; however, trophic plasticity is a common phenomenon in this infraorder of decapods. For example, Callianassa sub-

\footnotetext{
- Addressee for correspondence.

E-mail: r.j.a.atkinson@udcf.gla.ac.uk

- Present address: Department of Chemistry and Chemical Engineering, South Dakota School of Mines and Technology, Rapid City, South Dakota 57701, USA
}

terranea and Neotrypaea californiensis are both primarily deposit feeders but have also been observed to suspension feed (Hornig et al. 1989, Nickell \& Atkinson 1995), whilst Upogebia stellata, generally a suspension feeder, is also capable of deposit feeding (Nickell \& Atkinson 1995). Calocaris macandreae is regarded primarily as a deposit feeder (Buchanan 1963), although other feeding strategies, such as scavenging, suspension feeding and cannibalism, have been reported (Calderon-Perez 1981, Pinn 1995). Qualitative reports on the diet of thalassinideans suggest that they are detritivores and that the diet of different species is very similar, regardless of the mechanisms used to obtain the food (Harris et al. 1991, Pinn et al. 1997). The dietary similarity and trophic plasticity of these decapods raises questions regarding niche partitioning and resource utilization where species distributions averlap. Differences in particle selectivity may be one route through which intraspecific and interspecific competition is reduced.

Analyses of the gut contents of detritivores are complicated by the nondescript nature of the material 
being consumed. Identifiable material usually constitutes only a very small proportion of the entire gut contents (Harris et al. 1991, Pinn 1995). Another approach used for dietary analysis involves the characterization of the gut contents not in terms of digestible material but in terms of inorganic particle size. This method has been applied to other invertebrates (Fenchel et al. 1975, Whitlatch 1980, Levinton \& DeWitt 1989). It is this approach that has been adopted in the present study to examine resource partitioning in 5 species of Thalassinidea. For the purposes of the present study Callianassa subterranea and Calocaris macandreae were considered to be deposit feeders, Jaxea nocturna a re-suspension feeder and Upogebia deltaura and $U$. stellata suspension feeders.

\section{MATERIALS AND METHODS}

Specimen collection and details. Thalassinideans were collected at various times between November 1991 and October 1994. Calocaris macandreae were caught at 2 sites in the Firth of Clyde, Scotland: in the Main Channel off the Isle of Cumbrae $\left(50^{\circ} 46^{\prime} \mathrm{N}\right.$, $\left.04^{\circ} 58^{\prime} \mathrm{W}\right)$ and off Holy Island $\left(55^{\circ} 31^{\prime} \mathrm{N}, 05^{\circ} 4^{\prime} \mathrm{W}\right)$, using a $2 \mathrm{~m}$ Agassiz trawl. The mean carapace length (excluding rostrum and given as mean \pm standard deviation) of the specimens used in this study was 15.1 $\pm 1.9 \mathrm{~mm}$. Upogebia stellata and $U$. deltaura were collected using a Forster anchor dredge from White Bay, Isle of Cumbrae $\left(54^{\circ} 47^{\prime} \mathrm{N}, 04^{\circ} 54^{\prime} \mathrm{W}\right)$, also in the Firth of Clyde. The mean carapace length of the $U$. stellata specimens was $10.1 \pm 2.4 \mathrm{~mm}$, whilst that of $U$. deltaura was $11.7 \pm 1.6 \mathrm{~mm}$. Divers collected Callianassa subterranea and Jaxea nocturna from Caol Scotnish in Loch Sween, Argyll $\left(56^{\circ} 0^{\prime} \mathrm{N}, 05^{\circ} 36^{\prime} \mathrm{W}\right)$, a sheltered sea loch on the west coast of Scotland. Additional $C$. subterranea specimens were caught from a second site in Loch Sween, off Rubha na Stiùire. The divers used an Alvey king-size bait pump to 'suck' the thalassinideans from their burrows, a technique similar to that described by Manning (1975). The mean carapace length of the $J$. nocturna specimens was $10.7 \pm 2.8 \mathrm{~mm}$, and that of $C$. subterranea $12.6 \pm 1.6 \mathrm{~mm}$.

Particle size analysis. An analysis was made of the mineral grain size distribution within the foregut, midgut and hindgut of Callianassa subterranea, Upogebia stellata and $U$. deltaura and within the foregut and midgut of Jaxea nocturna and Calocaris macandreae. For these latter species, no hindgut results were available owing to the time that elapsed between capture of the specimens and their death (approximately $1.5 \mathrm{~h}$ ). The musculature of the hindgut works independently from that of the midgut, with peristalsis occurring more rapidly in the hindgut
(Bignell 1984), resulting in the hindgut being cleared of its contents before the midgut contents enter the hindgut. For C. macandreae this occurred within approximately 1 h of capture.

The particle size analysis was carried out using a Nikon light microscope fitted with an eye-piece graticule. The maximum diameter of 200 sediment grains was measured from the foregut, midgut and hindgut. All the grains within randomly selected fields of view were measured until the grain total was reached. Fenchel et al. (1975) found that the measurement of 200 to 400 grains gave reasonably reproducible results when examining the particle size distribution in the guts of the amphipod Corophium volutator and the prosobranch Hydrobia ulvae. With the exception of Callianassa subterranea and Calocaris macandreae, 3 replicates were carried out for each of the species, giving a total of 600 grain size measurements for each region of the gut. For both $C$. macandreae and $C$. subterranea 3 replicates were used for each of the 2 sites from which animals were obtained.

To allow a direct comparison with the gut contents results, a similar particle size analysis was carried out on the sediment from White Bay, the Main Channel, Holy Island, and the 2 sites in Loch Sween. With the exception of the Loch Sween sites, the sediment samples were collected using a Craib corer, and surface sediment $(0$ to $0.5 \mathrm{~cm})$ was collected for analysis. In Loch Sween, the sediment samples were collected by divers using hand-held corers and a similar depth of sediment was retained for analysis. Because Upogebia stellata and $U$. deltaura are suspension feeders, a similar particle size analysis was carried out on an integrated water sample obtained from 0 to $5 \mathrm{~cm}$ above the sediment surface in White Bay. These undisturbed samples were collected using a Craib corer and analyzed with an Olympus inverted microscope.

The particle size distributions within the gut and the environment in which the shrimps lived were compared statistically. To enable sensible analysis of the results obtained, trophic plasticity was generally ignored, and only the dominant trophic mode was considered for each species, i.e. Callianassa subterranea and Calocaris macandreae were considered to be deposit feeders, Jaxea nocturna a re-suspension feeder and the 2 upogebiids suspension feeders. For the Upogebia spp., however, the gut contents were also compared with habitat sediment, as this was the methodology used in previous work on particle selectivity in Upogebia spp. (e.g. Pearse 1945. Schaefer 1970, Powell 1974, Dworschak 1987).

A Mann-Whitney $U$-test showed no significant difference in the particle size distribution of the different regions of the gut for each species, so the results for each region were combined, giving a maximum of 
1800 measurements per species per site. Similarly, a Mann-Whitney $U$-test showed no significant difference between the 2 sites from which Calocaris macandreae specimens were obtained, and again the results were amalgamated, giving a total of 3600 grain size measurements for this species. For Callianassa subterranea, however, a significant difference $(p<0.05)$ between sites was observed, with Rubha na Stiùire being much sandier than $\mathrm{Caol}$ Scotnish. The results for these sites were therefore dealt with separately. The particle size selectivity was examined using the Kolmogorov-Smirnov test. Due to limitations on the number of specimens available for the present study, it was not possible to examine interspecific variations in particle size selectivity in relation to the sex and size of the mud shrimps, as has been reported for other decapod species (e.g. Jayachandran \& Joseph 1989)

\section{RESULTS}

Although there was some degree of variability, for both Calocaris macandreae and Jaxea nocturna, no significant difference was found between the particle size distributions of the gut and sediment from their respective environments (Fig. 1). The KolmogorovSmirnov test demonstrated that there was no statistically significant difference between the particle size distributions observed in the gut and the habitat sediment for these 2 species (Table 1).

The results of the particle size-frequency analyses from the guts of Upogebia stellata and $U$. deltaura showed that inorganic material in the gut was much finer than that of habitat sediment (Fig, 2A, B). Within the guts of these organisms, 76.9 and $80.0 \%$ of the sediment grains measured less than $4 \mu \mathrm{m}$ in diameter for $U$. stellata and $U$. deltaura, respectively. Within the substrata of White Bay, the natural environment of both Upogebia spp, the corresponding proportion was $32.8 \%$. Conversely, particles greater than $20 \mu \mathrm{m}$ diameter contributed only 1.0 and $0.2 \%$ of all particles within the guts of $U$. stellata and $U$. deltaura, respectively, although they comprised $10.7 \%$ of White Bay sediment. The Kolmogorov-Smirnov test showed that these differences were significant $\left(p<0.001_{\text {i }}\right.$ Table 1$)$. When the particle size ranges in the gut were compared with those in the surrounding water, however, the distributions were found to be similar for both species of Upogebia (Fig. 2C, D). The KolmogorovSmirnov test also indicated the absence of any particle selectivity (Table 1).

Callianassa subterranea specimens were obtained from 2 sites whose sediments differed significantly in terms of the grain size distributions $(p<0.05)$ (Fig. 3A). The sediment from Rubha na Stiuire was coarser, with

\section{A) Calocaris macandreae}

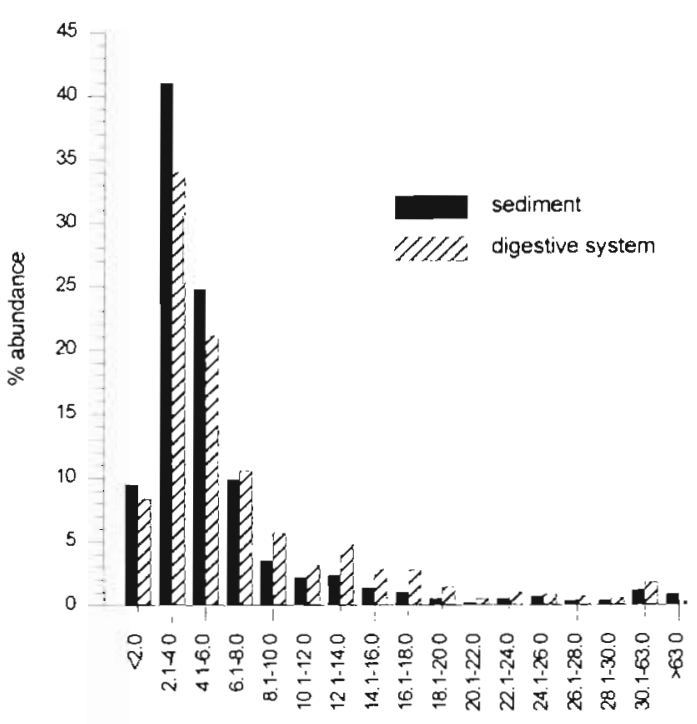

B) Jaxea nocturna

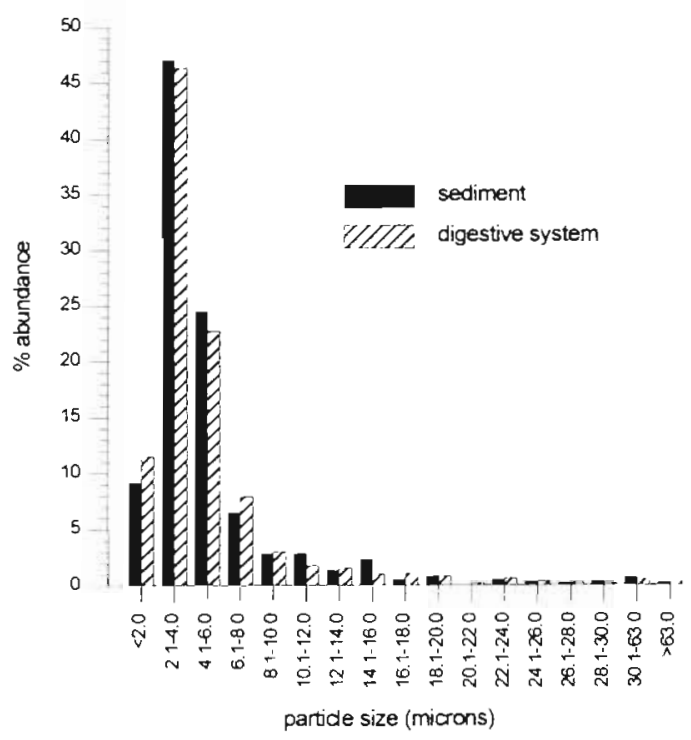

Fig. 1 Comparison of the distribution of particle sizes observed for the habitat of (A) Calocaris macandreae and (B) Jaxea nocturna with that observed in their guts

a greater sand content $(12.7 \%>63 \mu \mathrm{m}$ for Rubha na Stiuire and $1.3 \%>63 \mu \mathrm{m}$ for Caol Scotnish). The size distributions of the inorganic sediment grains observed in the gut of the C. subterranea specimens from the different sites were, however, relatively similar (Fig. 3B), with $59.0 \%$ of the grains observed in the gut of specimens from Caol Scotnish $<4 \mu \mathrm{m}$ and $62.3 \%$ for specimens from Rubha na Stiuire. Similarly, the sand fraction (>63 $\mu \mathrm{m}$ ) only accounted for $0.9 \%$ of the particles 
Table 1. Kolmogorov-Smirnov test results for differences between the distribution of particle sizes in the habitats (Firth of Clyde and Argyll. Scotland; see 'Materials and methods') and guts of 5 Thalassinidea species. ns: not significant

\begin{tabular}{|llcc|}
\hline Species & \multicolumn{1}{c}{ Substrate } & $D$ & $\begin{array}{c}\text { Significance } \\
\text { level }\end{array}$ \\
\hline Calocaris macandreae & Main Channel sediment & 0.085 & ns at 0.05 \\
Jaxea nocturna & Caol Scotnish sediment & 0.078 & ns at 0.05 \\
Callianassa subterranea & Caol Scotnish sediment & 0.032 & ns at 0.05 \\
& Rubha na Stiüire sediment & 0.375 & 0.001 \\
Upogebia stellata & White Bay sediment & 0.441 & 0.001 \\
& White Bay water & 0.070 & ns at 0.05 \\
Upogebia deltaura & White Bay sediment & 0.462 & 0.001 \\
& White Bay water & 0.085 & ns at 0.05 \\
\hline
\end{tabular}

in the gut of the specimens from Caol Scotnish and $0.5 \%$ of those from Rubha na Stiùre. The grain size distribution observed for the sediment from Caol Scotnish was very similar to that observed in the gut of the C. subterranea specimens from this site (Fig. 3C). The lack of any selectivity was confirmed by the Kolmogorov-Smirnov test (Table 1). For the shrimp from Rubha na Stiùire, however, there was a noticeable difference in the grain size distributions observed in the gut relative to the environment (Fig. 3D). The Kolmogorov-Smirnov test demonstrated that particle selectivity was occurring (Table 1 )

\section{DISCUSSION}

On the basis of the inorganic mineral grains found in the gut, Calocaris macandreae and the Callianassa subterranea specimens from Caol Scotnish are nonselective deposit feeders, Jaxea nocturna a non-selective re-suspension feeder and the 2 Upogebia spp. non-selective suspension feeders. The $C$. subterranea specimens obtained from Rubha na Stiùire, however, displayed selective deposit feeding. These individuals positively selected particle sizes $<4 \mu \mathrm{m}$ and rejected particles $>63 \mu \mathrm{m}$. Some evidence of positive selection for smaller particles by this species has been provided by Stamhuis (1997). He reported that within the gut of C. subterranea from the North Sea, sediment grains were almost exclusively $<30 \mu \mathrm{m}$, whilst in the surrounding sediment the bulk of the sediment grains were between $70 \mu \mathrm{m}$ and $150 \mu \mathrm{m}$. Intraspecific variation in particle selectivity has been observed for other invertebrates. Kleppel (1988) and Swadling \& Marcus (1994) both reported evidence of selective and nonselective feeding in adults of the copepod Acartia tonsa. Levinton \& DeWitt (1989) showed that, when large particles are rare, the snail Hydrobia totteni feeds indiscriminately. However, if small particles are rare, they are selected for by the snails. The intraspecific variation in particle selectivity demonstrated by $C$. subterranea probably enables this shrimp to significantly improve its diet when necessary.

Particle selectivity has been examined in a number of Thalassinidea and is well known for members of the Upogebiidae, for which there is often a predominance of smaller sediment particles in the gut relative to the habitat. Examples of this have been observed for Upogebia affinis (Pearse 1945), U. africana (Schaefer 1970), $U$. pugettensis (Powell 1974, Hornig et al. 1989), U. deltaura (Ngoc-Ho 1984) and $U$. pusilla (Dworschak 1987). Several callianassids have also been shown to be suspension feeders, and, correspondingly, small sediment grains dominated in their digestive tracts, for example, Callichirus (as Callianassa) major (Pohl 1946) and Callianassa filholi (Devine 1966). It should be noted that all these studies compared the grain sizes in the gut with those from the sediment in the environment rather than with the water that was being filtered. In the present study, when the size of the inorganic particles in the gut of $U$. stellata and $U$. deltaura were compared with those from the sediment of their environment, the difference in granulometry suggested positive selection for smaller sediment grains. However, when compared with the size distribution of the inorganic particles in the water column close to the sediment/water interface where these upogebiids feed, no size selection was found for these 2 filter-feeding species. Similar findings may also apply to other suspension-feeding thalassinideans.

Contrary to the findings of the present work, Pinn et al. (in press) reported selective feeding in Upogebia stellata when a comparison between the organic material in the gut contents and the water column was carried out. In the present work it is physical mechanisms, such as filtering through the setal fringes of the mouthparts, that would be expected to operate in particle size selectivity. Approximately $90 \%$ of the inorganic particles in the water column were $<6 \mu$ m diameter. Intersetal distances on the mouthparts are of this order (Pinn 1995). It can be assumed, therefore, that particles $<6 \mu$ m diameter would easily pass through the mouthparts and, hence, no evidence of particle selectivity would be observed. Pinn et al. (in press) suggest that, in addition to physical mechanisms for improving the diet, $U$. stellata also used chemosensory techniques to significantly increase the amount of organic material consumed 


\section{A) Upogebia stellata}

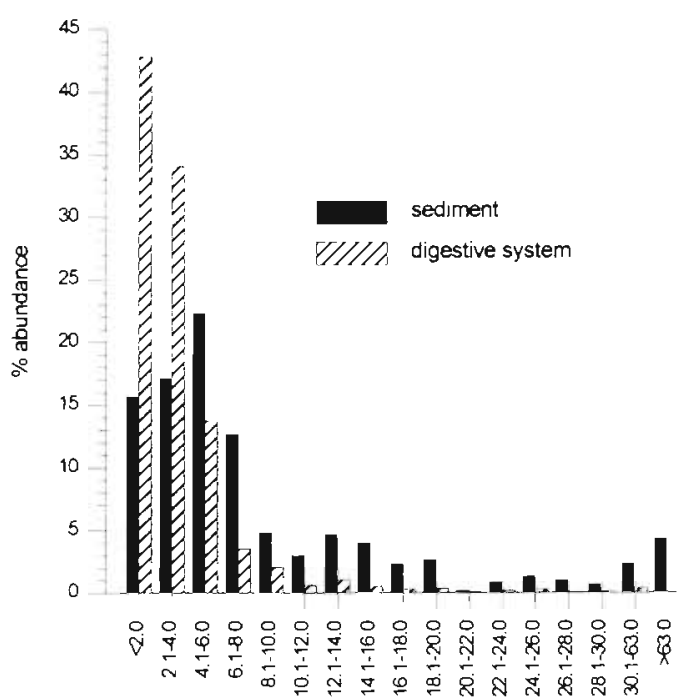

\section{C) Upogebia stellata}

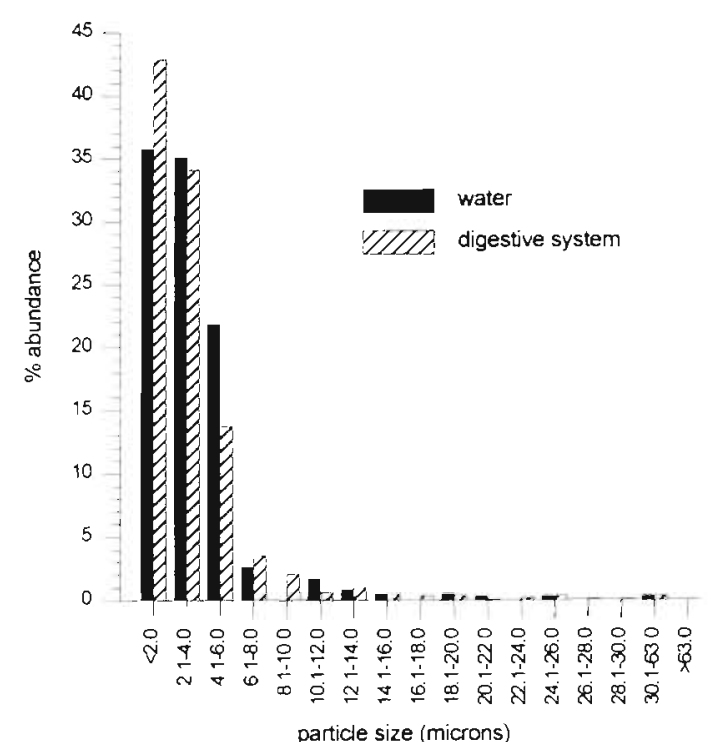

B) Upogebia deltaura

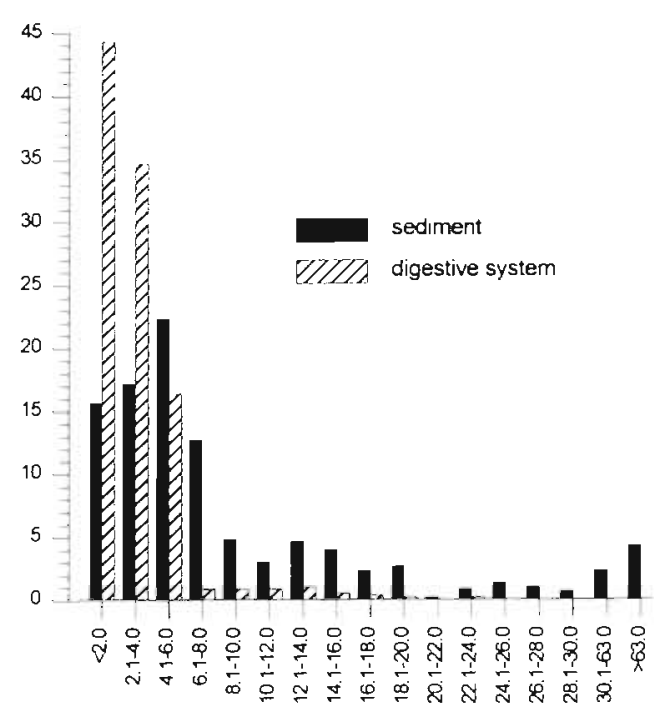

D) Upogebia deltaura

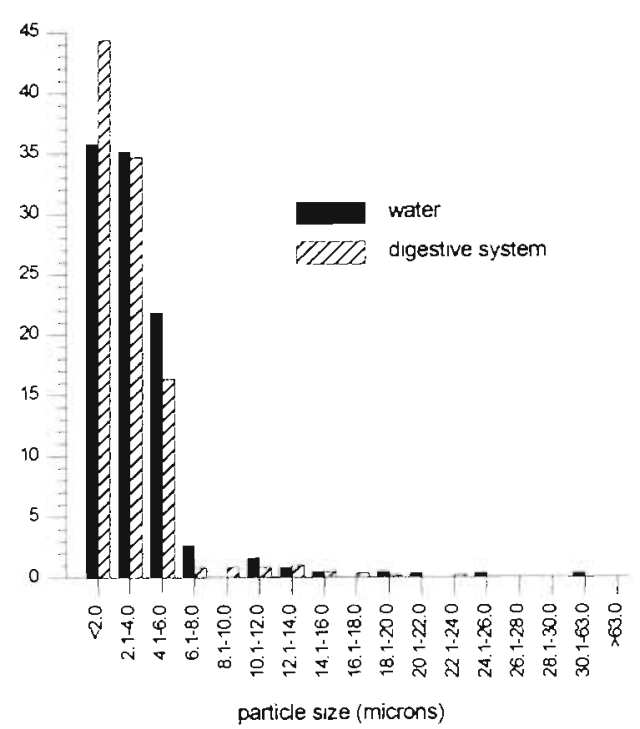

Fig. 2. Comparison of the distribution of particle sizes observed for the habitat sediment of (A) Upogebia stellata and (B) U. deltaura with that observed in their guts, and comparison of the distribution of particle sizes observed for the habitat water of (C) U. stellata and (D) U. deltaura with that observed in their guts

The results obtained in the present study suggest that, when examining inorganic mineral grains in the gut, resource partitioning does not occur through particle size selectivity. To some extent, dietary competition will probably be reduced both intraspecifically and interspecifically as thalassinideans generally feed within the confines of their burrow. In addition, burrow architecture may play some role in resource partitioning. In Loch Sween, Callianassa subterranea builds a burrow with a wide vertical inhalant shaft and a narrower exhalant shaft, both of which extend from the sediment surface to a horizontal lattice of tunnels and chambers (Nickell \& Atkinson 1995). The maximum recorded burrow depth is $86 \mathrm{~cm}$, although Nickell \& Atkinson (1995) state that this is likely to be an underestimate. Callianassa subterranea continuously changes the shape of its burrow through the processing of sub-surface sediment. The burrows of this tha- 
A) Habitat comparison

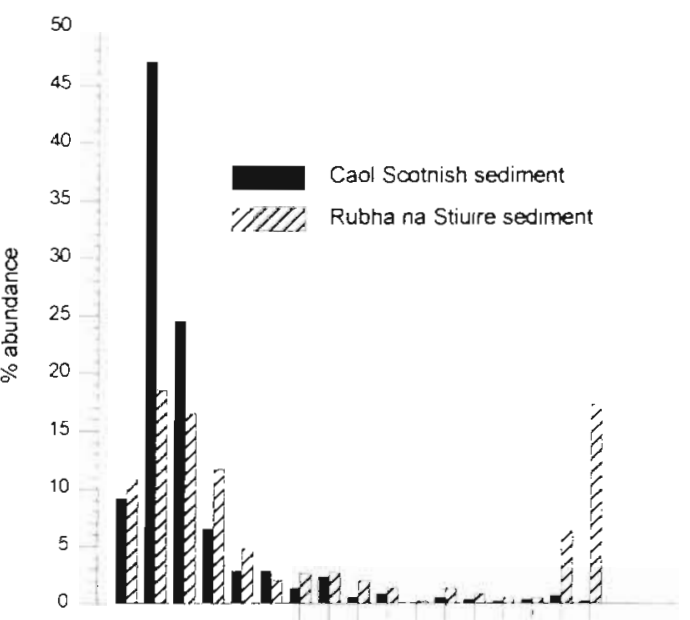

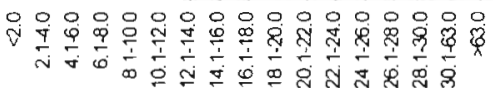

C) Caol Scotnish

Callianassa subterranea

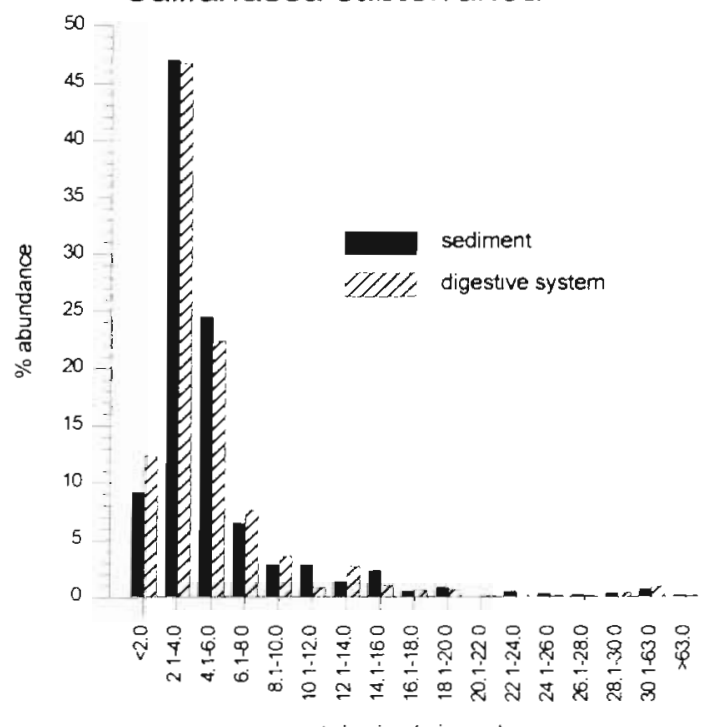

B) Digestive system comparison

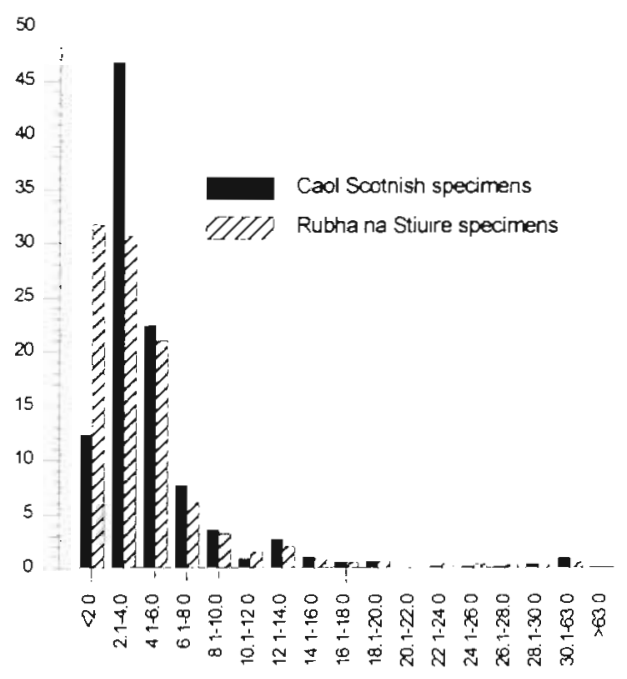

D) Rubha na Stiùire Callianassa subterranea

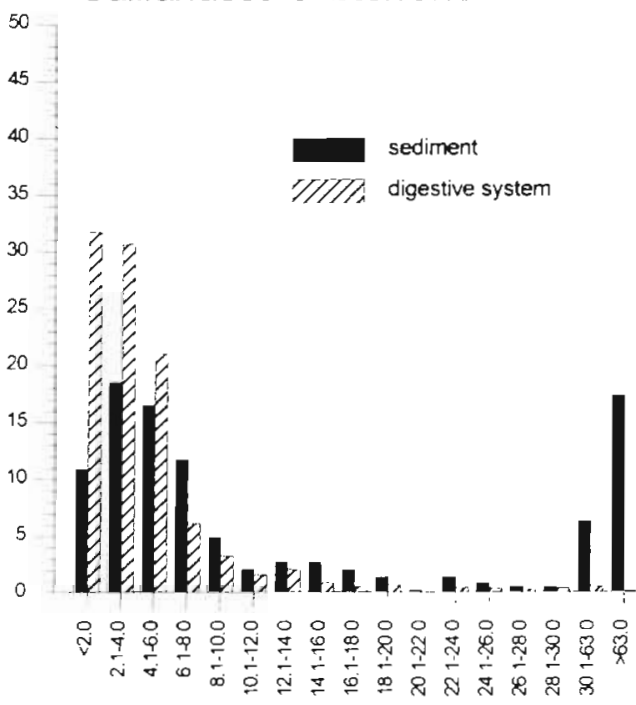

particle size (microns)

Fig. 3. Comparisons of (A) the habitat sediment and (B) sediment observed in the gut for the 2 sites from which Callianassa subterranea was collected, and comparison. of the distribution of particle sizes observed for the habitat sediment and the gut of $C$. subterranea at (C) Caol Scotnish, and (D) Rubha na Stiùire

lassinidean are, therefore, very dynamic and tend to migrate through the sediment.

Pervesler \& Dworschak (1985) and Nickell \& Atkinson (1995) have described the burrows of Jaxea nocturna. This thalassinidean constructs a burrow with up to 7 openings which usually have a characteristic crenate appearance. From these openings, tunnels descend at an angle between $20^{\circ}$ and $45^{\circ}$ from hori- zontal and converge to become a wide, spirally oriented, gently sloping main tunnel. In addition to these tunnels, there are 1 or 2 vertical shafts which join the main tunnel at 20 to $90 \mathrm{~cm}$ below the surface sediment. These burrows have a greater permanence in the sediment than those of C. subterranea. In addition, J. nocturna has regularly been observed subducting surface material into the burrow. Where the distributions of $J$. 
nocturna and C. subterranea overlap, such as observed in Loch Sween, resource partitioning will occur to some extent through the use of different sediment horizons.

Although the Calocaris macandreae specimens used in the present study were obtained from the Clyde sea area, this species also resides in Loch Sween (Atkinson 1987). Nash et al. (1984) and Pinn (1995) described the burrows of this thalassinidean as having a tripartite branching pattern, which is usually reflected in the presence of groups of 3 openings to the sediment surface. The branching pattern gives rise to a secondary level of circular tunnels at the deepest burrow horizon, approximately $30 \mathrm{~cm}$ from the sediment surface (Nash et al. 1984, Pinn 1995). This shallow burrow depth may be one way in which competition between this species and Jaxea nocturna and Callianassa subterranea is reduced in Loch Sween. C. macandreae has been reported to take macrofauna and algal detritus into its burrow, some of which is fed on directly and the remainder packed into the burrow walls possibly for the purpose of microbial gardening (Nash et al. 1984, Pinn 1995). This may also represent another form of resource partitioning

Upogebia stellata is also known to be present in Loch Sween (Atkinson 1987). Nickell \& Atkinson (1995) described the burrows of $U$. stellata as typically $U$ or $Y$ shaped burrows whose openings are flush with the sediment surface. An additional shaft, originating from the base of the $U$ at $90^{\circ}$ to the other 2 shafts, extends towards the sediment surface. The junction of this shaft with the main burrow complex is expanded to form a small chamber. In the present study, $U$. stellata were collected from White Bay, where their distribution overlaps that of $U$. deltaura. Astall et al. (1997) reported a similar burrow description for $U$. deltaura. With similar burrow types and trophic modes, resource partitioning between these 2 species is not obvious. It is possible that the quality and quantity of food does not require variations in resource utilization. However, whilst collecting the specimens for the present study, it was noted that $U$. deltaura was generally obtained from shallower depths than $U$. stellata. It may be through this depth variation that resource partitioning accurs

Whilst much is known about thalassinidean burrow morphology, there is a distinct lack of accurate, quantitative information about mud-shrimp feeding and nutrition. The cryptic nature of these decapods, in combination with their trophic plasticity and intraspecific variation in particle selectivity, makes the collection of such information very difficult. However, if models linking burrow morphology and feeding are to become more accurate, it is essential that such research be carried out.

\section{LITERATURE CITED}

Astall CM, Taylor AC. Atkinson RJA (1997) Behavioural and physiological implications of a burrow-dwelling lifestyle for two species of upogebiid mud-shrimp (Crustacea: Thalassinidea). Estuar Coast Shelf Sci 44:155-168

Atkinson RJA (1987) The burrowing megafaunal communities of the upper arms of Loch Sween. Report to the Nature Conservancy Council, Peterborough. University Marine Biological Station, Millport, p 1-65

Bignell DE (1984) The arthropod gut as an environment for microorganisms. In: Anderson JM, Rayner ADM. Walton DWH (eds) Invertebrate-microbial interactions. Cambridge University Press, Cambridge, p 205-227

Buchanan JB (1963) The biology of Calocaris macandreae (Crustacea: Thalassinidea). J Mar Biol Assoc UK 43: $729-747$

Calderon-Perez JA (1981) Some aspects of the biology of Calocaris macandreae Bell (Crustacea: Decapoda; Thalassinidea) in Isle of Man waters. PhD thesis, University of Liverpool

de Vaugelas JV (1990) Ecologie des callianasses (Crustacea, Decapoda, Thalassinidea) et milieu récifal Indo-Pacifique. Conséquences du remaniement sédimentaire sur la distribution des matieres humiques, des métaux trace et des radionucléides. Memoire présenté a l'Université de Nice, p $1-269$

Devine CE (1966) Ecology of Callianassa filholi MilneEdwards 1878 (Crustacea, Thalassinidea). Trans R Soc NZ Zool 8:93-110

Dworschak PC (1987) Feeding behaviour of Upogebia pusilla and Callianassa tyrrhena (Crustacea, Decapoda, Thalassinidea). Invest Pesq 51:421-429

Fenche] T, Kofoed LH, Lappalainen A (1975) Particle size analysis of two deposit feeders: the amphipod Corophium volutator and the prosobranch Hydrobia ulvae. Mar Biol $30: 119-128$

Griffis RB, Suchanek TH (1991) A model of burrow architecture and trophic modes in thalassinidean shrimp (Decapoda: Thalassinidea). J Exp Mar Biol Ecol 117:239-253

Harris JM, Seiderer LJ, Lucus MF (1991) Gut microflora of two saltmarsh detritivore thalassinid prawns, Upogebia africana and Callianassa kraussi. Microb Ecol 21:277-296

Hornig S, Sterling A, Smith SD (1989) Species profiles: life histories and environmental requirements of coastal fishes and invertebrates (Pacific North West): ghost shrimp and blue mud shrimp. US Fish Wild Serv Biol Rep 82:1-15

Jayachandran KV, Joseph NI (1989) Food and feeding habits of the slender river prawn, Macrobrachium idella (Hilgendorf, 1898) (Decapoda, Palaemonidae). Mahasagar 22: $121-129$

Kleppel GS (1988) Plant and animal pigments as trophodymanic indicators. In: Soule DF, Kleppel GS (eds) Marine organisms as indicators. Springer-Verlag, New York, p 73-90

Levinton JS, DeWitt TH (1989) Relation of particle size spectrum and food abundance to particle selectivity in the mud snail Hydrobia totteni (Prosobranchia: Hydrobiidae). Mar Biol 100:449-454

Manning RB (1975) Two methods for collecting decapods in shallow water. Crustaceana 29:317-319

Nash RDM, Chapman CJ, Atkinson RJA, Morgan PJ (1984) Observations on the burrows and burrowing behaviour of Calocaris macandreae (Crustacea: Decapoda: Thalassinidea). J Zool 202:425-439

Ngoc-Ho N (1984) The functional anatomy of the foregut of Porcellana platyceles and a comparison with Galathea 
squamifera and Upogebia deltura (Crustacea: Decapoda). J Zool 203:511-535

Nickell LA, Atkinson RJA (1995) Functional morphology of burrows and trophic modes of three thalassinidean shrimp species, and a new approach to the classification of thalassinidean burrow morphology. Mar Ecol Prog Ser 128:181-197

Ott JA, Fuchs B, Fuchs R, Malasek A (1976) Observations on the biology of Callianassa stebbinigi Borrodaille and Upogebia litoralis Risso and their effect upon the sediment. Senckenberg Marit 8:61-79

Pearse AS (1945) Ecology of Upogebia atfinis (Say). Ecology 26:303-305

Pervesler P, Dworschak PC (1985) Burrows of Jaxea nocturna Nardo in the Gulf of Trieste. Senckenberg Marit 17:33-53

Pinn EH (1995) Studies on the feeding biology of thalassinidean mud-shrimps. PhD Thesis, University of London

Pinn EH, Atkinson RJA, Rogerson A (in press) The diet of two mud-shrimps, Calocaris macandreae and Upogebia stellata (Crustacea: Decapoda: Thalassinidea). Ophelia

Pinn EH, Rogerson A, Atkinson RJA (1997) Microbial flora associated with the digestive system of Upogebia stellata (Crustacea: Decapoda: Thalassinidea). J Mar Biol Assoc UK 77:1083-1096

Editorial responsibility: Otto Kinne (Editor), Oldendorf/Luhe, Germany
Pohl ME (1946) Ecological observations on Callianassa major Say at Beaufort, North Carolina. Ecology 27:71-80

Powell RR (1974) Functional morphology of the foreguts of the thalassinid crustaceans Callianassa califormiensis and Upogebia pugettensis. Univ Calif Publ Zool 102:1-41

Schaefer N (1970) The functional morphology of the foregut of three species of decapod Crustacea: Cyclograpus punctatus Milne-Edwards, Digenes brevirostris Stimpson and Upogebia africana (Ortmann). Zool Afr 5:309-326

Stamhuis EJ (1997) Mining, brushing and flushing. Feeding mechanism, turbative activity and behavioural energetics of the endobenthic thalassinid shrimp Callianassa subterranea. $\mathrm{PhD}$ thesis, University of Gröningen

Suchanek TH (1985) Thalassinid shrimp burrows: ecological significance of species-specific architecture. In: Delesalle B (ed) Proc 5th Coral Reef Congr, Tahiti, 5: p 205-210

Swadling KM, Marcus NH (1994) Selectivity in the natural diets of Acartia tonsa Dana (Copepoda: Calanoida): comparison of juveniles and adults. J Exp Mar Biol Ecol 181: 91-103

Whitlatch RB (1980) Patterns of resource utilisation and coexistence in marine intertidal deposit-feeding communities. J Mar Res 38:743-765

Submitted: April 14, 1998; Accepted: June 8, 1998

Proots received from author(s): July 23, 1998 
Oceanogr 42:974-980

Hays GC (1995) Zooplankton avoidance activity. Nature 376: 650

Hays GC, Warner AJ, Lefevre D (1996) Long-term changes in the diel vertical migration behaviour of zooplankton. Mar Ecol Prog Ser 141:149-159

Huang C, Uye S, Onbé T (1993) Ontogenetic diel vertical migration of the planktonic copepod Calanus sinicus in the Inland Sea of Japan. III. Early summer and overall seasonal pattern. Mar Biol 11.7:289-299

Huntley M, Brooks ER (1982) Effects of age and food avail- ability on diel vertical migration of Calanus pacificus. Mar Biol 71:23-31

Last JM (1989) The food of the herring, Clupea harengus, in the North Sea, 1983-1986. J Fish Biol 34:489-501

Marshall SM, Orr AP (1927) The relation of the plankton to some chemical and physical factors in the Clyde Sea area. J Mar Biol Assoc UK 14:837-868

Russell FS (1928) The vertical distribution of marine macroplankton. VII. Observations on the behaviour of Calanus finmarchicus in relation to light intensity. J Mar Biol Assoc UK 15:429-454

\title{
Erratum
}

\section{Particle size selectivity and resource partitioning in five species of Thalassinidea (Crustacea: Decapoda)}

\author{
Eunice H. Pinn, R. James A. Aikinson, Andrew Rogerson
}

Mar Ecol Prog Ser 169: 243-250, 1998

- The comma after 'James' in the list of author names on the title page was incorrect. The second author's correct full name is 'R. James A. Atkinson' 